\title{
Equine joint disease in the light of new developments in articular cartilage research
}

\author{
P. R. van Weeren and P. A. J. Brama
}

Department of Equine Sciences, Faculty of Veterinary Medicine, Utrecht University

\begin{abstract}
Summary
Lesions of articular cartilage form a prominent source of wastage in athletic horses. This is largely due to the fact that repair of these lesions is known to be insufficient in mature individuals, which leads to chronic pathology and eventual invalidity. Recent research on basic biology and developmental aspects of equine cartilage has led to a more profound insight into the fundamental processes that underlie and influence joint pathology. This paper presents a synopsis of this work, placed in the context of related studies in other species. From biochemical studies on all main components of the extracellular matrix (ECM) of articular cartilages (collagen, proteoglycans and water), it has become clear that in mature individuals a marked topographic heterogeneity exists throughout the joint surface. Biomechanical studies on the tissue level have shown that there is a clear relationship between biochemical tissue characteristics and biomechanical performance, i.e. response to loading. On the other hand, biomechanical studies at the level of the entire joint show a close correlation between degree of loading under physiological conditions and biochemical composition. Main finding is that collagen content and degree of crosslinking is high at sites that are subjected to high, but intermittent loading, whereas proteoglycans are prominent at more constantly, but less heavily loaded sites. Studies into the developmental aspects of biochemical heterogeneity have shown that such heterogeneity does not exist at birth, but develops during early life. This development can be influenced (temporarily or permanently depending on the biochemical parameter) through manipulation of the exercise level the young individual is subjected to. From these findings a novel concept of the relationship of cartilage function and structure and of the development of the biochemical and biomechanical characteristics of the tissue emerges. In this concept it is the degree of exercise in the immature animal that largely determines the biochemical characteristics of the ECM of articular cartilage. In the mature individual no essential alterations of the collagen part of this ECM can be incited anymore by any means due to the rapid decrease in ECM (especially collagen) metabolism that starts after birth and brings the remodelling rate sharply down during the first year of life. As the biochemical characteristics of the collagen network are intricately linked to biomechanical behaviour, and thus to stress resistance, the foundation of the ultimate quality of articular cartilage is thus irreversibly laid at young age. New data on the developmental orthopaedic disease osteochondrosis (OC), in which a clear distinction is made between the pathogenesis of lesions and the ensuing repair process, are in line with this concept. In OC, lesions have been shown to be capable of complete repair until a certain age only. After that age, the decrease in cartilage metabolism precludes full repair and clinical lesions will remain. This concept of functional adaptation of articular cartilage as a once in a lifetime process strongly underlines the importance of the early postnatal period for the development of sound articular cartilage. A practical consequence is that young equines should be given ample opportunity for exercise, a requirement that conflicts with some developments in modern stud management. However, exercise should not be excessive as there are strong indications that too much or wrongly balanced exercise may be deleterious as well and may even have negative long-term effects.
\end{abstract}

Keywords: horse, articular cartilage, collagen, osteoarthritis, osteochondrosis, functional adaptation

\section{Die Gelenkerkrankung des Pferdes im Licht neuer Entwicklungen der Gelenkknorpelforschung}

Verletzungen des Gelenkknorpel stellen eine herausragende Ursache für Verluste beim Sportpferd dar. Ursache dafür ist die Tatsache, dass die Regenerationsfähigkeit des Gelenkknorpels beim erwachsenen Pferd eingeschränkt ist, was zur chronischen Erkrankung und ggf. zur Invalidität führt. Neue Forschungen über grundlegende biologische und entwicklungsphysiologische Aspekte des Gelenkknorpels beim Pferd führten zu profunderen Kenntnissen der Gelenkpathologie zugrundeliegenden Vorgänge. Die Studie ist eine vergleichende Darstellung dieser Forschungen im Zusammenhang mit verwandten Untersuchungen bei anderen Spezies. Biochemische Studien über die hauptsächlichen Komponenten der extrazellulären Matrix (ECM) des Gelenkknorpels (Kollagen, Proteoglykane und Wasser) zeigten, dass beim erwachsenen Individuum eine gewisse topographische Heterogenität der Gelenkoberfläche besteht. Biochemische Gewebsstudien wiesen auf einen klaren Zusammenhang von biochemischen Gewebscharakteristika mit der biomechnischen Belastungsfähigkeit bzw. Reaktion auf Belastung hin. Andererseits ergaben biomechnische Untersuchungen aller Gelenksstrukturen eine enge Korrelation zwischen dem Grad der Belastung unter physiologischen Bedingungen und der biochemischen Zusammensetzung. Das wichtigste Ergebnis ist, dass der Kollagengehalt und das Ausmaß des Cross linking in den starker, aber intermittierender Belastung ausgesetzten Bereichen hoch sind, wohingegen an gleichmäßiger, aber weniger stark belasteten Stellen die Proteoglykane vorherrschen. Untersuchungen über entwicklungsphysiologische Aspekte der biochemischen Heterogenität zeigten, dass diese zum Zeitpunkt der Geburt nicht existiert, sondern sich erst in der frühen Lebenphase entwickelt. Diese Entwicklung kann abhängig von den biochemischen Parametern zeitweilig oder permanent durch Veränderung der Bewegungsintensität des jungen Individuums beeinflusst werden. Diese Befunde ergeben ein neuartiges Konzept der Verbindung von Knorpelfunktion und Knorpelstruktur mit der Entwicklung der biochemischen und biomechanischen Eigenschaften. Es ist der Grad der Bewegunsginensität des jungen Tieres, der die biochemischen Charakteristika der ECM des Gelenkknorpels bestimmt. Beim ausgewachsenen Individuum können keine wesentlichen Veränderungen des Kollagenanteils der ECM mehr provoziert werden. Grund dafür ist die schnelle Vermindung der ECM, besonders des Kollagenanteils, die kurz nach der Geburt beginnt und die im ersten Lebensjahr die 
Remodelling-Rate mehr und mehr mindert. Da die biochemischen Eigenschaften des Kollagennetzwerks auf komplizierte Weise mit dem biomechnischen Verhalten und damit der Belastungsresistenz verbunden sind, wird die bleibende Qualität des Gelenkknorpels im frühen Alter irreversibel festgelegt. Nevere Erkenntnisse über die Osteochondrose (OC), bei der eine klare Unterscheidung zwischen Pathogenese der Läsion und dem nachfolgenden Reparaturprozess gemacht wird, stimmen mit diesem Konzept überein. Bei der OC zeigt sich, dass die Läsionen bis zu einem bestimmten Alter komplett ausheilen können. Danach verhindert der reduzierte Knorpelmetabolismus eine völlige Heilung und es bleiben klinische Läsionen. Das Konzept der funktionellen Anpassung des Gelenkknorpels innerhalb eines bestimmten Lebenszeitraums unterstreicht die Wichtigkeit der frühen postnatalen Periode für die Entwicklung eines gesunden Gelenkknorpels. Praktische Konsequenz ist, dass Fohlen ausreichend Gelegenheit zum Auslauf zu geben ist, ein Bedürfnis, das mit manchen Entwicklungen des modernen Gestütsmanagements kollidiert. Jedoch sollte die Bewegung auch nicht zu exzessiv sein, weil kein Zweifel daran besteht, dass zu starke und schlecht ausgewogenen körperliche Belastung des Fohlens ebenso schädlich sein und ebenso zu negativen Lanzeitfolgen führen kann.

Schlüsselwörter: Gelenkknorpel, Kollagen, Osteoarthritis, Osteochondrose, Arthrose, funktionelle Anpasung

\section{Introduction}

The horse differs in some important aspects from the other domesticated species. Horses not only were domesticated rather late in history (about 3000 BC, small ruminants were domesticated about 7000 years earlier; Dunlop and Williams 1996), the primary objective of domestication was different as well. Whereas the other large species were domesticated to provide meat, milk, fur, skin or other material goods, horses have been primarily used from the start of domestication for their locomotor performance, which became crucial for warfare, transport and agriculture. Nowadays, it is still the locomotor system that gives the horse its role in present-day society as a well-appreciated sports and leisure animal.

Given the use of the horse, it is no surprise that ailments of the musculoskeletal system are common and are in fact the most important cause of wastage and untimely retirement (Rossdale et al. 1985, Williams et al. 2001). Among acute lesions in racing Thoroughbreds tendon injuries prevail (Williams et al. 2001), amidst the more chronic disorders of the locomotor system in the equine species pathological changes of articular cartilage are dominating (Todhunter 1992). Articular cartilage, tendon and, to a certain extent, the many ligaments that can be found in the equine musculoskeletal system have a few important features in common. These tissues all have a high to very high extracellular matrix to cell ratio and they have, at least in the mature animal, a bad tendency to heal once damage has occurred. For articular cartilage this was already observed by William Hunter in 1743, who stated that damaged cartilage would never recover (Fig. 1). Also for tendons it is known that healing is notoriously

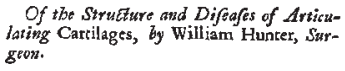

If we confult the ftandard Chirurgical Writers from Hippocrates down to the prefent Age, we fhall find, that an ulcerated Cartilage is univerfally allowed to be a very troublefome Difeafe; that it admits of a Cure with more Difficulty than a carious Bone; and that, when deftroyed, it is never recovered.

\section{Read June 2}

Fig. 1 Facsimile reproduction of the original text by William Hunter as published in the Philosophical Transactions of the Royal Society of London in 1743.

Faksimile des Originaltextes von William Hunter, veröffentlicht 1743 in Philosophical Transactions of the Royal Society of London. incomplete and will never lead to repair tissue with the same quality as the original tissue (Watkins 1999). Because these tissues are so vital for a good performance of the equine locomotor system, and because of their vulnerability and susceptibility to injury, a good insight in the basic biology and physiology of these structures is essential for the equine veterinarian. In fact, this basic knowledge is needed too for every owner or trainer who makes athletic demands upon his or her horses.

In recent years much research effort has been dedicated to the fundamental aspects of equine articular cartilage and its development in the young, growing horse. From this research a novel concept has emerged of the function of equine cartilage, its adaptation to athletic demand and the way such functional adaptation is acquired. These new insights may have consequences for the management, and especially the rearing, of equine athletes and may question some practices that are becoming common in certain areas. This paper gives a synopsis of this work, placed in the broader context of the great scientific advances that have been made in fundamental matrix biology in other species, including man. After an introductory paragraph on the basic principles of articular cartilage matrix biology, an overview is given of recent advances in the specific equine field. The final part aims at evaluating the significance of these developments for everyday practice and tries to define areas which look promising for future research.

\section{Articular cartilage biochemistry}

\section{Extracellular matrix composition}

The hyaline cartilage that covers the articular surfaces of diarthrodial joints is a highly specialised connective tissue with biomechanical characteristics that make it particularly suitable for load bearing and shock absorption. A sparse population of chondrocytes (1-2\% of the volume), is distributed throughout the extracellular matrix, which consists mainly of collagen, proteoglycans and water. The physical properties of the tissue depend on the structure and organisation of the macromolecules in the extracellular matrix. The collagen molecules are organised in a dense cross-linked fibrillar network that is packed with proteoglycans which are strongly negatively charged as a result of their polyanionic glycosaminoglycan chains. In this way a large osmotic swelling pressure is created, drawing water into the tissue and expanding the collagen network. It is this balance within the extracellular 
matrix between the tension in the collagen network and the osmotic swelling pressure of the proteoglycans that gives articular cartilage its unique mechanical characteristics as it provides a combination of high compressive stiffness with a large degree of resiliency. These properties are critically dependent on both the integrity of the collagen network (including cross-linking and lysyl-hydroxylation) and the synthesis and retention of proteoglycans (Kempson 1980, Eyre and Wu 1995, Palmer and Bertone 1996, van Weeren and Brama 2001, Todhunter 1996).

\section{Topographical heterogeneity}

Different areas of articular cartilage are subject to different types of loading, such as low-level constant loading, intermittent loading, and very high impact loading. These variable loading conditions can only adequately be met (without provoking damage in the long term) by articular cartilage featuring different mechanical properties (Palmer and Bertone 1996). As biomechanical properties and biochemical composition of tissues are intricately interwoven, this is only possible when there are topographical differences in biochemical characteristics. Biochemical and biomechanical heterogeneity of articular cartilage has indeed been reported in man (Maroudas et al. 1973) and in other species such as dogs (Kiviranta et al. 1987, Jurvelin et al. 2000), sheep (Armstrong et al. 1995), and cattle (Lewis et al. 1998).

There is some evidence that these topographical differences in extracellular matrix composition may be not yet present at birth. Little and Ghosh (1997) showed that in neonatal ovine articular cartilage, in contrast to tissue from mature individuals, there was neither heterogeneity in proteoglycan biochemistry nor in chondrocyte metabolism. This brought them to the hypothesis that the regional chondrocyte phenotype of adult ovine cartilage resulted from factors imposed on the joint after birth, i.e. weight bearing and articulation. They did not, however, look at the principal structural component of the ECM, i.e. collagen, or at any of the collagen-related characteristics such as cross-linking.

\section{Extracellular matrix metabolism}

The two major constituents of the cartilage extracellular matrix, collagens and proteoglycans, have very different turnover rates. Turnover time of proteoglycans is variable, probably due to the existence of sub-populations, and ranges from as little as 3.5 to 1800 days. However, collagen turnover times have been estimated up to 120 years in dogs and 350 years in adult human cartilage (Maroudas 1980). No specific data are available for the horse, but it can be assumed that the order of magnitude will be similar. It should be explicitly stated that these values apply to mature individuals. In young, growing individuals there is a constant process of remodelling and growth, making turnover rates much higher. The extremely long turnover times in mature individuals are presumably related to the structural features of the mature collagen fibril. Once the collagen fibril has been synthesised and the covalent cross-links (mainly hydroxylysylpyridinoline or HP-crosslinks, to a much lesser extent lysylpyridinoline or LP-crosslinks) have formed within and between molecules in the fibril, the sites available for enzymatic cleavage are limited. This gives the triple helical collagen great resistance to proteolytic attacks and hence these are turned into rather static tissue components (Maroudas 1980, Eyre et al. 1991, Maroudas et al. 1992, Todhunter 1996). It is therefore likely that the notorious and long-known very limited capacity for repair of articular cartilage as alluded to earlier (Hunter 1743) originates from the virtually absent turnover of the collagen network in mature individuals.

\section{Research on extracellular matrix composition and deve- lopment of articular cartilage in the horse}

Extracellular matrix composition and the development of topographical heterogeneity

The first report on the composition of the ECM of equine articular cartilage dates from the early 90s (Vachon et al. 1990). However, interest in the normal situation seemed to fade quickly as virtually all later biochemical work focussed at repair tissue (Barr et al. 1994), or cartilage specimens from specific disorders such as osteochondrosis (Lillich et al. 1997). In some cases normal tissue was investigated together with pathological samples (Todhunter et al. 1994). Much work was performed on assessing the effect of a variety of drugs on cartilage metabolism and composition, or on the regulation of cartilage metabolism under physiological and pathological conditions. However, more basic studies such as the one characterising the different sub-populations of proteoglycans in different layers (of human femoral head) cartilage (Mitrovic and Darmon 1994) were totally lacking in equine orthopaedic literature. Site differences in the proteoglycan content of the ECM of equine articular cartilage were, however, reported as a sequel to exercise (Palmer and Bertone 1995), an environmental factor that was proven to influence proteoglycan metabolism (Little et al. 1997). On a parallel track, Murray et al. (1995) demonstrated variations in biomechanical properties of articular cartilage in the midmetacarpal joint, an area that is known to be frequently affected by degenerative joint disease.

In 1999 Brama et al. published a first report on site (and age) related differences in the biochemical characterisation of the collagen network at two sites of the proximal articular surface of the first phalanx (Brama et al. 1999a). They showed a significantly higher collagen content at the dorsal rim of the articular surface than in the central fovea. Numbers of crosslinks were higher too. It was demonstrated in a more extensive study, in which 12 different sites were sampled, that there was a distinct and consistent topographical variation for all biochemical parameters that were determined: water, DNA, glycosaminoglycans, collagen, HP cross-links and degree of lysyl hydoxylation (Brama et al. 2000a) (fig. 2). The findings corresponded neatly with the load distribution in the joint as determined using pressure-sensitive films in an in vitro setting in which loads were applied that occur during activities such as standing, walking, trotting, cantering and jumping (Brama et al. 2001). From this study it became clear that there were huge differences in degree of loading throughout the joint. Whereas the central area is loaded during all activities, the dorsal rim is not loaded but during the most strenuous exercise (fig. 3). However, under those circumstances the load is 
almost double the load in the central fovea. This means that there is a wide scale of differently loaded areas: from sites that are constantly, but relatively mildly loaded, to areas that are intermittently, but very heavily loaded. In the latter area collagen content is high, but glycosaminoglycan (GAG) content is low, in the more constantly loaded areas the situation is reverse. This pattern is consistent with findings in human intervertebral discs where Scott et al. (1994) demonstrated that increasing compressive loads corresponded with higher
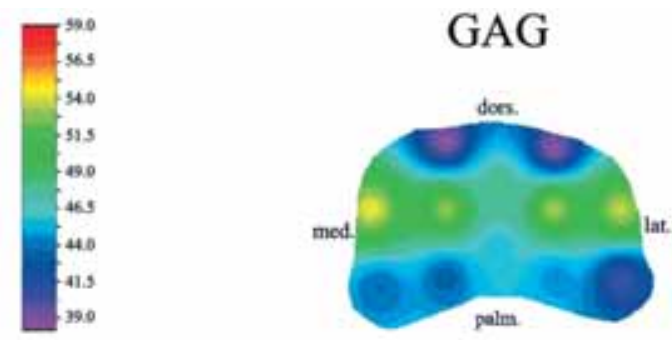

A

\section{Collagen}

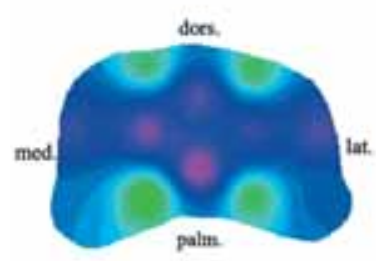

B

\section{Crosslinking}

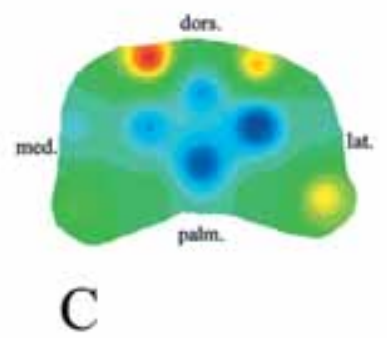

Fig. 2a-c Topographical patterns of some measured biochemical parameters on the proximal articular surface of the first phalanx in the fetlock joint. dors.=dorsal; GAG=glycosaminoglycan; Crosslinking=hydroxylysylpyridinoline (HP) cross-links; lat. $=$ lateral; med. =medial; palm.=palmar. (Adapted from Brama et al. Equine vet. J. 32(2000), 19-26).

Topographische Muster einiger biochemischer Parameter auf der proximalen Gelenkoberfläche des Fesselbeins.

GAG-levels while higher collagen levels correlated with greater ranges of torsional and shearing strain. Cross-links are highest at the intermittently, but heavily loaded sites too, presumably in order to withstand the high forces that are generated. Cross-linking is higher medial than lateral, which is likely to be caused by the asymmetric loading in the life animal because of the central, and hence abaxial, position of the centre of gravity. In the in vitro draw bench experiment (Brama et al. 2001) this asymmetric loading was not taken into account, but Brommer et al. (2003) showed in a large population of horses that osteoarthritis (OA) was more frequently seen at the medial side of the joint than at the lateral side. The degree of lysyl hydroxylation largely mirrors collagen content and cross-linking and thus seems inversely related to biomechanical strength. This is in line with earlier findings in bone where elevated hydroxylysine levels in collagen type I were associated with lower biomechanical strength (Yang et al. 1993, Knott et al. 1995).

In an age range of 4-30 years it was demonstrated that the site-related differences (or at least those between the most extremely loaded sites) remained constant throughout life

(Brama et al. 1999a). However, it remained yet to be proven that the hypothesis of Little and Ghosh (1997), which was based on studies of ovine articular cartilage, applied to the horse as well (and to other components of the ECM than GAGs alone). A first investigation into the biochemical composition of neonatal equine articular cartilage showed that there were indeed no differences for all biochemical parameters investigated, including those relating to collagen, between the two sites that are most different in the mature ani-
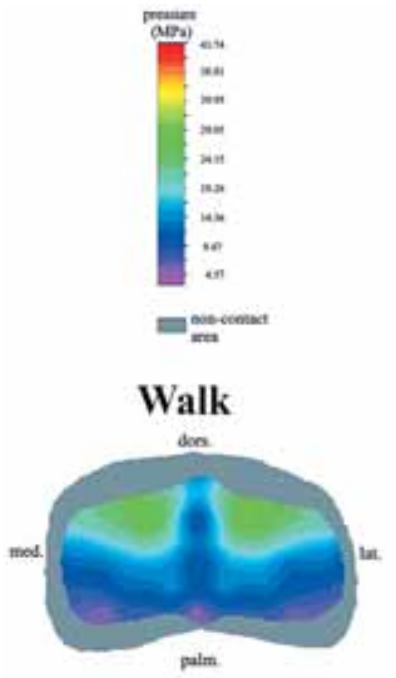

B

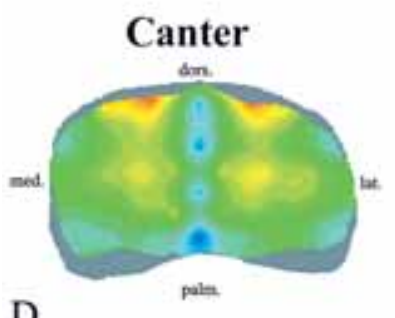

D

Fig. 3a-c Loading patterns (MPa) and contact areas on the proximal articular surface of the first phalanx in the fetlock joint under different loading conditions mimicking various physiological conditions. dors.=dorsal; lat.=lateral; med.=medial; $\mathrm{MPa}=$ megapascal; palm. $=$ palmar. Adapted from Brama et al. Equine vet. J. 33(2001), 26-32).

Belastungsmuster (MPa) und Kontaktbereiche auf der proximalen Gelenkoberfläche des Fesselbeins unter verschiedenen Belastungsintensitäten in Nachahmung verschiedener physiologischer Belastungszustände.

mal (Brama et al. 2000b). Site-specific differences had developed at the age of 5 months for DNA, GAGs, collagen and lysyl hydroxylation, but were still absent for water and HP cross-linking at age 11 months. The picture became complete when these data were combined with data from older animals: the ratios between the two sites for these parameters became significantly different from zero in the age span of 1 4 years (Brama et al. 2002) (Fig. 4). It is interesting to note that most of the topographical heterogeneity takes shape in the first 5 months of life, which therefore seems to be a crucial period.

Little and Ghosh (1997) presumed that the development of topographical heterogeneity was initiated by the onset of articulation and weight-bearing after birth. Brama et al. (1999b) 
showed in a study on the effect of exercise on the biochemical composition of the articular ECM of young foals that withholding of exercise (box-rest) led to a significantly lower GAG-content than in pastured foals. This study was part of a much larger investigation into the influence of exercise on the development of the equine musculoskeletal system in general and on osteochondrosis in particular (van Weeren and Barneveld 1999). The difference disappeared when normal exercise was given after the age of 5 months. Changes in colla-

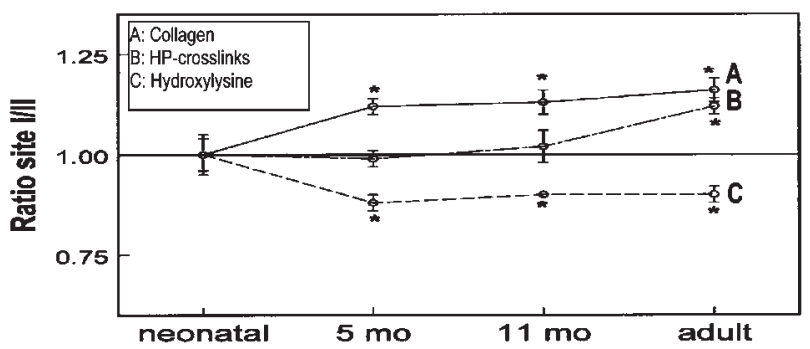

Fig. 4 Ratio between two differently loaded sites on the proximal articular surface of the proximal phalanx (site I located at the dorsal margin of the joint and site II at the central fovea) with respect to contents of collagen (a), HP crosslinks (b), and hydroxylysine (c). *: ratio significantly different from one, i.e. existence of significant site differences $(p<0.05)$. (Adapted from Brama et al., Equine vet. J. 34 (2002), 265-269).

Verhältnis zwischen zwei unterschiedlich belasteten Bereichen der proximalen Gelenkoberfläche des Fesselbeins (Bereich I am dorsalen Gelenkrand und Bereich II in der zentralen Fovea) bezüglich den Gehalten an Kollagen (a), HP-Crosslinks (b) und Hydroxilysin (c).

gen parameters between the groups could not be demonstrated. However, in that study only one site (the central fovea) was examined. In the same material the differences in biochemical composition between that area and the dorsal rim of the first phalanx were studied. It then appeared that significant topographical differences had failed to develop at age 5 months in the box-rested foals with respect to both total collagen and degree of lysyl hydroxylation (Brama et al. 2002). The most striking finding was that these differences did not develop either during a 6-month period of normal exercise, after the cessation of the period of box confinement at age 5 months (Fig. 5). Therefore, withholding of exercise at young age seems to have a lasting effect on ECM-composition.

\section{Osteochondrosis}

Support for the vital importance of the early postnatal period with respect to joint development comes from another area of equine orthopaedic research too. The developmental orthopaedic disease osteochondrosis (OC) has in recent years been shown to be much more dynamic in character than thought before. After the first indications that lesions may still develop in young animals (Carlsten et al. 1993), Dabareiner et al. (1993) showed that small lesions might disappear as well. Later, Dik et al. (1999) demonstrated that in the first months of life radiographically visible lesions may come and go, including those in which distinct fragments are present. However, the same authors showed that after a certain age that varied per joint but did not exceed 12 months, the situation remained static (Fig. 6). This research led to the view that discrimination should be made between the pathogenesis of
$\mathrm{OC}$ lesions and the ensuing repair process. The resultant of both processes determines whether a mature individual will have a lesion or not, i.e. final clinical outcome. The two processes seem to be very different in nature and may be influenced by different factors. It was for instance shown very recently that liver copper content at birth is not related to the pathogenesis of lesions, but does affect the repair process of existing lesions (van Weeren et al. 2003). Whereas the real pathogenesis of $\mathrm{OC}$ remains largely unknown (Jeffcott and

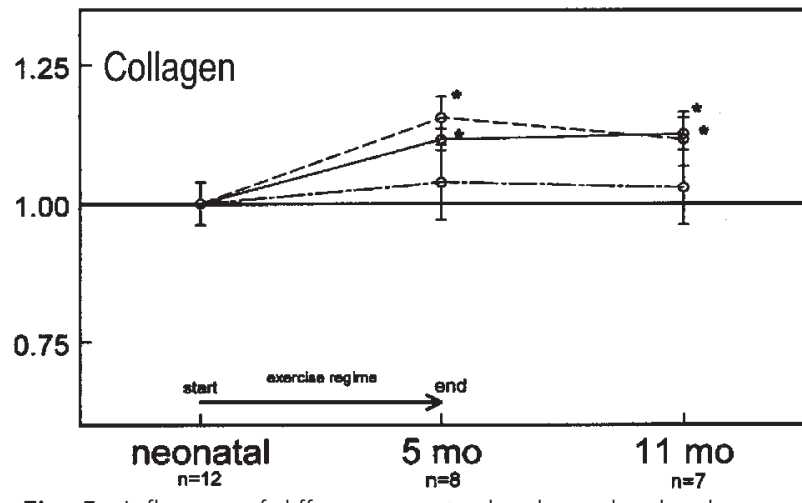

Fig. 5 Influence of different exercise levels on the development of topographical heterogeneity in collagen content. Foals were trained for 5 months $(----=$ pasture exercise $24 \mathrm{~h} /$ day; - $=$ box-rest with additional 30 minutes of intensive training; --_-_---_- = box-rest 24h/day). After 5 months exercise was equal for all groups. Note that the lack of exercise induced a delay in the development of topographical heterogeneity that was not compensated for when box confinement ceased. *: ratio significantly different from one, i.e. existence of significant site differences $(p<0.05)$. (Adapted from Brama et al., Equine vet. J. 34 (2002), 265-269)

Einfluss unterschiedlicher Belastungsgrade auf die Entwicklung der topographischen Heterogenität des Kollagengehalts. Die Fohlen wurden 5 Monate lang trainiert. Nach 5 Monaten war die Belastung für alle Gruppen gleich. Zu beachten ist, dass das Fehlen körperlicher Belastung eine Verzögerung der Entwicklung der topographischen Heterogenität auslöst, was mit späterer Aufnahme des Trainings nicht wieder ausgeglichen werden kann.

\section{Development of $\mathrm{OC}$ lesions in stifle}

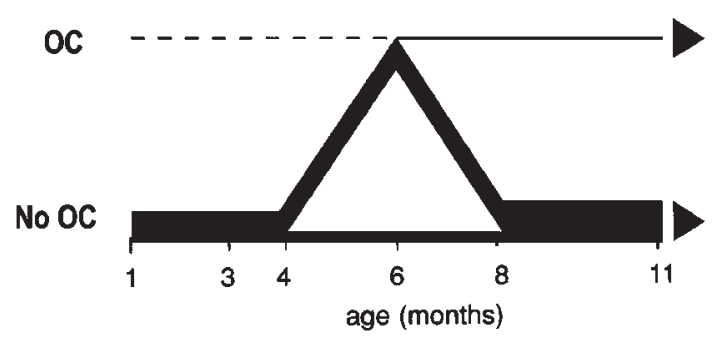

Fig. 6 During early life osteochondrotic lesions come and go. In the stifle most lesions develop after age 3 months and dissolve before age 8 months. Some will remain and may become clinically relevant lesions. (Adapted from Dik et al., Equine vet. J. Suppl. 31 (1999), 9-15).

In der frühen Entwicklungsphase können osteochondrotische Veränderungen auftreten und auch wieder verschwinden. Im Kniegelenk entwickeln sich die meisten OC-Läsionen nach einem Alter von 3 Monaten und können bis zum Alter von 8 Monaten wieder vollständig ausheilen. Bleiben Sie bestehen, werden sie möglicherweise klinisch relevant.

Henson 1998), it lies at hand to presume that the capacity for repair is related to the level of cartilage metabolism. This explains the rapid decline in the maturing individual of the 
capacity for full repair of $O C$ lesions, and the essential cessation of repair of these lesions at the age of about one year.

\section{Discussion}

From the recent research a new concept of the composition and development of equine articular cartilage emerges. The distinct biochemical heterogeneity as is found in the mature animal is clearly loading-related. The studies on contact areas and loading pressures of the same articular surface showed an almost perfect lateral to medial symmetry (which was partly due to the experimental set-up, as pointed out before), but in a palmar to dorsal direction substantial differences in loading existed. This coincides with the sequential and increasing loading of the joint surface during a stride cycle when the fetlock, after the onset of weight-bearing at hoof contact, is increasingly loaded during the process of gradually increasing extension until the moment of maximal extension before hoof liff-off. In fact, loading increased from palmar to dorsal with highest loads measured at the dorsal articular margin where, when mimicking loads during athletic activity, pressures were measured that were more than 10-fold the pressures determined at the central articular area during stance. This highly loaded dorsal articular margin does not come into contact with the opposing joint surface during stance or at the slower gaits, and hence is only intermittently loaded, in contrast to the central areas of the joint surface which are continuously loaded, irrespective of the activity of the animal. This loading pattern is reflected in the mature animal in the sitespecific biochemical make-up of the articular cartilage in which collagen content (and cross-link numbers) match with high intermittent loads and a high proteoglycan content seems best to counteract lower, but more constant loads.

The studies on biochemical composition of the ECM in various age classes demonstrated that at birth this topographical heterogeneity as is characteristic for the mature individual does not yet exist. The topographical heterogeneity is for the largest part formed during the first phase of life when cartilage metabolism is still high. This high metabolic level may and remodelling rate may be related to the fact that up to age 7 months blood vessels can still be found in the ECM of articular cartilage in the form of so-called cartilage canals (Carlson et al. 1995). Van den Hoogen et al. (1999) showed that the maximal metabolic capacity in terms of 35S-incorporation of equine chondrocytes at 11 months of age was more than $30 \%$ lower than at age 5 months. It is of utmost importance to note that this process of transformation from biochemical homogeneity to topographical heterogeneity, or of functional adaptation as it has been called (Brama et al. $2000 \mathrm{~b}$ ), is to a large part a unique once in a lifetime process. The process seems to be an inherent and consistent characteristic of articular cartilage biology as similar findings have been made in other species and with different techniques (Helminen et al. 2000). It is also the juvenile period, which in itself obviously differs per species, that emerges from this research as the absolutely critical phase. It is true that in recent research, exercise has been shown to influence the mechanical properties of equine articular cartilage in mature individuals (Murray et al. 1999) and the biochemical composition of it (Murray et al. 2000, 2001). However, these effects did not relate to the collagen network, which is incontestably the main structural element of the ECM, and the most important element in terms of pathology.

The consequences of this concept are far-reaching. Insufficient exercise at early age may lead to insufficient functional adaptation and hence to a cartilage layer that is less apt to withstand the demands made by athletic performance. The rapid decrease in cartilage metabolism, the loss of vascular supply because of the disappearance of the cartilage canals, and/or the increased density of the collagen network through cross-linking that makes it less accessible for proteolytic enzymes, negatively influence the remodelling rate. These processes give the insufficient functional adaptation or, in case of $O C$, existing lesions a permanent and irrevocable character. It is not more than logic, though yet not proven that animals with insufficient functional adaptation are more prone to injury and might more easily develop chronic degenerative joint disorders.

These data strongly plea to provide the newly born foal with ample opportunity for exercise. However, care should be taken, as not all types of exercise appear to be beneficial. In the same study as quoted earlier it was shown that foals that had been kept in box-stalls, but were given additional highintensity exercise, did indeed not show any retardation in functional adaptation (Brama et al. 2002). However, the metabolism of their chondrocytes could not be stimulated anymore by adding serum when in culture, which was interpreted as a kind of exhaustion (Van den Hoogen et al. 1999). As parameters from other tissues indicated similar effects, it was concluded that the combination of box-rest and highintensity exercise had a deleterious effect (Barneveld and van Weeren 1999). A very significant additional finding was that in case of several parameters this deleterious effect was still present 6 months after the exercise regimen had been normalised. Studies on collagen biomarkers in the serum of these same groups of foals very recently gave a further indication of the negative effect on cartilage metabolism. This was evidenced as a significant increase in collagen type II degradation and a decrease in synthesis of this collagen in animals that had undergone the combination of forced exercise and box-rest (Billinghurst et al. 2003). In this study too, the negative effect was still evident long after the exercise regimen had been changed, which can be interpreted as an ominous sign for future cartilage quality.

So far, unrestricted pasture exercise comes out best. It remains to be seen whether the combination of pasture exercise and additional exercise can steer the process of functional adaptation in such a way that the eventual tissue quality will be improved. Presently, a large-scale trial by an international consortium is underway in New Zealand that, among other things, aims at investigating this possibility (Mcllwraith 2000).

It is recognised that unrestricted pasture exercise for the equine neonate, though arguably better from a viewpoint of wellbeing as well, conflicts with the present-day desire for very "early foals", at least in those areas where climatic conditions preclude full-day turnout early in he year. It is known that nature never planned foals to be born very early in those temperate zones. Nature may have given us a good argument against the practice of "early foals": insufficient functional 
adaptation of articular cartilage may not only affect the wellbeing of the animal, it may also have negative consequences for performance, or at least longevity, of the mature equine athlete.

\section{Literature}

Armstrong S.J., Read R.A. and Price R. (1995): Topographical variation within the articular cartilage and subchondral bone of the normal ovine knee joint: a histological approach. Osteoarthritis and Cartilage 3, 25-33

Barneveld A. and van Weeren P.R. (1999): Conclusions regarding the influence of exercise on the development of the equine musculoskeletal system with special reference to osteochondrosis. Equine vet. J. Suppl. 31, 112-119

Barr A.R.S., Duance V.C, Wotton S.F., Waterman A.E. and Holt P.E. (1994): Quantitative analysis of cyanogen bromide-cleaved peptides for the assessment of Type I:Type II collagen ratios in equine articular repair tissue. Equine vet. J. 26, 33-39

Billinghurst C, Knowlton M, Brama P., van Weeren R. and Mcllwraith W. (2003): Serum levels of collagen biomarkers reflect exerciseinduced changes in cartilage. Proc. 49th Ann. Meeting Orthop. Res. Soc. (issued on CD)

Brama P.A.J., TeKoppele J.M., Bank R.A., van Weeren P.R. and Barneveld A. (1999a): Biochemical characteristics of the collagen network of equine articular cartilage: influence of site and age. Am. J. Vet. Res. 60, 341-345.

Brama P.A.J., TeKoppele J.M., Bank R.A., van Weeren P.R. and Barneveld A. (1999b): Influence of different exercise levels and age on the biochemical characteristics of immature equine articular cartilage. Equine vet. J. Suppl. 31, 55-61

Brama .PA.J., TeKoppele J.M., Bank R.A.Karssenberg D, Barneveld A. and van Weeren P.R. (2000a): Topographical mapping of biochemical properties of articular cartilage in the equine fetlock joint. Equine vet. J. 32, 19-26

Brama P.A.J., TeKoppele J.M., Bank R.A., Barneveld A. and van Weeren P.R. (2000b): Functional adaptation of equine articular cartilage: the formation of regional biochemical characteristics up to age one year. Equine vet. J. 32, 217-221

Brama P.A.J., Karssenberg D., Barneveld A. and van Weeren P.R. (2001): Contact areas and pressure distribution on the proximal articular surface of the proximal phalanx under sagittal plane loading. Equine vet. J. 33, 26-32

Brama P.A.J., TeKoppele J.M., Bank R.A., Barneveld A. and van Weeren P.R. (2002): The development of biochemical heterogeneity of articular cartilage from neonatal to adult and the influence of exercise. Equine vet. J. 34, 258-264

Brommer H. van Weeren P.R., Brama P.A.J. and Barneveld A. (2003): Quantification and age-related distribution of articular cartilage degeneration in the equine fetlock joint. Equine vet. J., accepted for publication.

Carlson C.S., Cullins L.D. and Meuten J.D. (1995): Osteochondrosis of the articular-epiphyseal cartilage complex in young horses: evidence for a defect in cartilage canal blood supply. Vet. Pathol. 32, $641-647$

Carlsten J., Sandgren B., and Dalín G. (1993): Development of osteochondrosis in the tarsocrural joint and osteochondral fragments in the fetlock joints of Standardbred trotters. I.A radiological survey. Equine Vet. J. Suppl. 16, 42-47

Dabareiner R.M., Sullins K.E. and White II N.A. (1993): Progression of femoropatellar osteochondrosis in nine young horses. Clinical, radiographic and arthroscopic findings. Vet. Surg. 22, 515-523

Dik K.J., Enzerink E. and van Weeren P.R. (1999): Radiographic development of osteochondral abnormalities, in the hock and stifle of Dutch Warmblood foals, from age 1 to 11 months. Equine vet. J. Suppl. 31, 4-8
Dunlop R.H. and Williams D.J. (1996): Veterinary Medicine. An illustrated history, Mosby, St. Louis.

Eyre D.R. and Wu J.J. (1995): Collagen structure and cartilage matrix integrity. J. Rheumatol. Suppl. 43, 82-85

Eyre D.R., Wu J. and Woods P.E. (1991): The cartilage collagens: structural and metabolic studies. J. Rheumatol. Suppl. 27, 49-51

Helminen H.J., Hyttinen M.M., Lammi M.J., Arokoski J.P.A., Lapveteläinen T., Jurvelin J., Kiviranta I. and Tammi M.I. (2000): Regular joint loading in the youth assists in the establishment and strengthening of the collagen network of articular cartilage and contributes to the prevention of osteoarthrosis later in life; A hypothesis. J. Bone Min. Metab. 18, 245-257

Hunter W. (1743): Of the structure and diseases of articulating cartilages. Phil. Trans. R. Soc. London 9, 514-521

Jeffcott L.B. and Henson F.M.D. (1998): Studies on growth cartilage in the horse and their application to aetiopathogenesis of dyschondroplasia (osteochondrosis). Vet. J. 126, 117-192

Jurvelin J.S., Arokoski J.P., Hunziker E.B. and Helminen H.J. (2000): Topographical variation of the elastic properties of articular cartilage in the canine knee. J. Biomech. 33, 669-675

Kempson G.E. (1980): The mechanical properties of articular cartilage. In: The joints and synovial fluid. vol 2., Ed: L. Sokoloff, Academic Press, New York. pp 177-238

Kiviranta I., Tammi M., Jurvelin J. and Helminen H.J. (1987): Topographical variation of glycosaminoglycan content and cartilage thickness in canine knee (stifle) joint cartilage. Application of the microspectrophotometric method. J. Anat. 150, 265-276

Knott L., Whitehead C.C., Fleming R.H. and Bailey A.J. (1995): Biochemical changes in the collagenous matrix of osteoporotic avian bone. Biochem. J. 310, 1045-1051

Lewis R.J., MacFarland A.K., Anandavijayan S. and Aspden R.M. (1998): Material properties and biosynthetic activity of articular cartilage from the bovine metacarpophalangeal joint. Osteoarthritis and Cartilage 6, 383-392

Lillich, J.D., Bertone, A.L., Malemud, C.J., Weisbrode, E., Ruggles, A.J. and Stevenson, S. (1997) Biochemical, histochemical and immunohistochemical characterisation of distal tibial osteochondrosis in horses. Am. J. Vet. Res. 58, 89-98.

Little C.B. and Ghosh P. (1997): Variation in proteoglycan metabolism by articular chondrocytes in different joint regions is determined by post-natal mechanical loading. Osteoarthritis and Cartilage $5,49-62$

Little, C.B., Ghosh, P. and Rose, R. (1997) The effect of strenuous versus moderate exercise on the metabolism of proteoglycans in articular cartilage from different weight-bearing regions of the equine third carpal bone. Osteoarthritis and Cartilage 5, 161172.

Maroudas A., Evans H. and Almeida L. (1973): Cartilage of the hip joint. Topographical variation of glycosaminoglycan content in normal and fibrillated tissue. Ann. Rheum. Dis. 32, 1-9

Maroudas A. (1980): Metabolism of cartilaginous tissues: A quantitative approach. In: Studies in Joint Disease. vol 1, Eds: A. Maroudas and E.J. Holborow, Pitman Medical, Tunbridge Wells. pp 59-86

Maroudas A., Palla G. and Gilav E. (1992): Racemization of aspartic acid in human articular cartilage. Connect. Tissue Res. 28, $161-169$

Mcllwraith C.W. (2000): Global Equine Research Alliance to reduce musculoskeletal injury in the equine athlete. Equine vet. Educ. (Am. Ed.) 2, 339-341

Mitrovic D.R. and Darmon N. (1994): Characterization of proteoglycans synthesized by different layers of adult human femoral head cartilage. Osteoarthritis and Cartilage 2, 119-131

Murray R.C., DeBowes R.M., Gaughan E.M., Mosier D.E. and Athanasiou K.A. (1995): Variations in the biomechanical properties of articular cartilage of the midcarpal joint of normal horses. Vet. Comp. Orthop. Traumatol. 8, 133-140

Murray R.C., Zhu C.F., Goodship A.E., Lakhani K.H., Agrawal C.M. and Athanasiou K.A. (1999): Exercise affects the mechanical properties and histological appearance of equine articular cartilage. J. Orthop. Res. 17, 725-731 
Murray R.C., Janicke H.C., Henson F.M.D. and Goodship A.E. (2000): Equine carpal articular cartilage fibronectin distribution associated with training, joint location and cartilage deterioration. Equine vet. J. 32, 47-51.

Murray R.C., Birch H.L., Lakhani K. and Goodship A.E. (2001): Biochemical composition of equine carpal articular cartilage is influenced by short-term exercise in a site-specific manner. Osteoarthritis and Cartilage 9, 625-632

Palmer J.L., Bertone A.L., Malemud C.J., Carter B.G., Papay R.S. and Mansour J. (1995): Site-specific proteoglycan characteristics of third carpal articular cartilage in exercised and nonexercised horses. Am. J. Vet. Res. 56, 1570-1576

Palmer J.L. and Bertone A.L. (1996): Joint biomechanics in the pathogenesis of traumatic arthritis. In: Joint disease in the horse, Eds: C.W. Mcllwraith and G.W. Trotter GW, W.B. Saunders, Philadelphia. pp 104-119

Rossdale P.D., Hopes R., Wingfield Digby N.J. and Offord K. (1985): Epidemiological study of wastage among racehorses. Vet. Rec. $116,66-69$

Scott J.E., Bosworth T.R., Cribb A.M. and Taylor J.R. (1994): The chemical morphology of age-related changes in human intervertebral disc glycosaminoglycans from cervical, thoracic and lumbar nucleus pulposes and annulus fibrosus. J. Anat. 184, 73-82

Todhunter R.J. (1992): Synovial joint anatomy, biology, and pathobiology. In: Equine Surgery, Ed: J.A. Auer, Saunders, Philadelphia, pp 844-866

Todhunter R.J., Wootton J.A.M., Altman N., Lust G. and Minor R.R. (1994): Cross-validation of cyanogen bromide-peptide ratios to measure the proportion of type II collagen in pepsine-digests of equine articular cartilage, meniscus and cartilage repair tissue. Anal. Biochem. 216, 195-204

Todhunter R.J. (1996): General principles of joint pathobiology. In: Joint disease in the horse, Eds: C.W. Mcllwraith and G.W. Trotter GW, W.B. Saunders, Philadelphia. pp 1-28
Vachon A., Keeley F.W., Mcllwraith C.W and Chapman P.C. (1990): Biochemical analysis of normal articular cartilage in horses. Am. J. Vet. Res. 51, 1905-1911

Van den Hoogen B.M., van de Lest C.H.A., van Weeren P.R., van Golde L.M.G. and Barneveld A. (1999): Effect of exercise on the proteoglycan metabolism of articular cartilage in growing foals. Equine vet. J. Suppl. 31, 62-66

Van Weeren P.R. and Barneveld A. (1999): Study design to evaluate the influence of exercise on the development of the musculoskeletal system of foals up to age 11 months. Equine vet. J. Suppl. 31, 4-8

Van Weeren P.R. and Brama P.A.J. (2001): Physiology and pathology of the equine joint. Pferdeheilk. 17, 307-318

Van Weeren P.R. Knaap J. and Firth E.C. (2003): Influence of liver copper status of mare and newborn foal on the development of osteochondrotic lesions. Equine vet. J., 35, 67-71

Watkins J.P. (1999): Tendon and ligament biology. In: Equine Surgery 2 nd ed., Eds: J.A. Auer and J.A. Stick, W.B. Saunders, Philadelphia. pp 704-711

Williams R.B., Harkins L.S., Hammond C. and Wood J.L.N. (2001): Racehorse injuries, clinical problems and fatalities recorded on British racecourses from flat racing and National Hunt racing during 1996, 1997 and 1998. Equine vet. J. 33, 478-486

Yang C., Niu C., Bodo M., Gabriel E., Notbohm H., Wolf E. and Müller P.K. (1993): Fulvic acid supplementation and selenium deficiency disturb the structural integrity of mouse skeletal tissue. Biochem. J. 289, 829-835

P.R. van Weeren DVM, PhD, Dipl. ECVS

Department of Equine Sciences, Faculty of Veterinary Medicine Utrecht University

Yalelaan 12, NL-3584 CM Utrecht

r.vanweeren@vet.uu.nl 